\title{
RESEARCH
}

\section{The Godfather of Left-Schmittianism? Otto Kirchheimer and Carl Schmitt after 1945}

\author{
Hubertus Buchstein \\ Greifswald University, DE \\ buchstei@uni-greifswald.de
}

In the vast secondary literature on Carl Schmitt as well as on the Frankfurt School, the political and legal thinker Otto Kirchheimer is described as a forerunner of contemporary Left-Schmittianism. This view is sometimes expanded in the literature to the personal relationship between Schmitt and Kirchheimer after 1945 as well. A closer look at Kirchheimer's late work, at his unpublished correspondence with Schmitt, and at additional unpublished sources contradicts such an interpretation. In fact, Kirchheimer strongly attacked Schmittianism in German debates on constitutional theory after 1945. This article finally uncovers the extent to which Schmitt tried to instrumentalize his former doctoral student to pursue his political rehabilitation in the Federal Republic via the United States. Kirchheimer, however, took a firm stand against this attempt. In his defense of modern parliamentary democracy, Kirchheimer definitely sided with the political left of his times; but he did so without any flirtation with Schmittianism.

Keywords: Otto Kirchheimer; Carl Schmitt; Left-Schmittianism; antisemitism; West German political and legal thought

\section{Introduction: Against Some Legends}

The work of Carl Schmitt (1888-1985) has become a point of reference for a growing number of contemporary political theorists on the left. The term 'Left-Schmittianism' was originally coined in the 1950s by Wolfgang Wieland in Germany with respect to social democratic disciples of Schmitt like Ernst-Wolfgang Böckenförde, and Schmitt liked this label (van Laak 1993, 238). Left-Schmittianism became a political explosive with the Schmitt reception by left revolutionaries like Mario Tronti in Italy, Johannes Agnoli in Germany and by theorists of the guerilla war in Latin America in the late 1960s (Preuss 2008; Müller 2003, 169-180). In the 1980s, Left-Schmittianism was the subject of academic controversies about the Frankfurt School, Walter Benjamin and the early work of Jürgen Habermas in particular (Kennedy 1986; Heil 1996; Zwarg 2017, 369-373). In contemporary political theory, authors such as Giorgio Agamben, Gopal Balakrishnan, Chantal Mouffe and Andreas Kalyvas refer towards different aspects of Schmitt's work to strengthen their left political projects (Specter 2016). 
Otto Kirchheimer (1905-1965) is often viewed as a forerunner of the different versions of Left-Schmittianism (Kennedy 1986, 382; Taubes 1987, 14; Mehring 2007, 61). He seems to fit perfectly into the role of a godfather of today's Left-Schmittianisms: He was a doctoral student of Schmitt from the radical left in the 1920s and he made extensive use of Schmitt's thinking in his own critical analysis of the Weimar Republic as a young constitutional and political theorist. Kirchheimer was one of several up-and-coming German-Jewish lawyers who were first put in jail and later were able to escape into exile after the Nazi Government took power in 1933. He struggled as an impoverished intellectual for a couple of years in Paris and in New York. During the war, he worked in the Office of Strategic Services (OSS) in Washington DC and later for the US State Department. In 1954, he was able to build his career as a political scientist at the New School for Social Research and took a position at Columbia University in 1961. Kirchheimer died in 1965 . He was buried at the Jewish cemetery in Heilbronn, Germany.

Kirchheimer's rich academic oeuvre reflects the range of his political and academic experiences in the Weimar Republic, under National Socialism, in French and American exile, and during the founding and establishment of the two newly emerging German states after 1945. Today he is well known for his work as a critical analyst of the Weimar Constitution and Germany's Nazi legal system, as a member of the Frankfurt School in exile, as an inspirer of Foucault's Critical Criminology, as a member of the OSS team preparing the Nuremberg trials, as a European politics researcher in the State Department, as the inventor of the concept of the 'catch-all party' in comparative political science and as the author of the acclaimed book Political Justice (Schale 2006; Schale, Klingsporn \& Buchstein 2018; Buchstein 2020a).

However, in the secondary literature, all these facets of Kirchheimer's oeuvre are overshadowed by the fact that he was Schmitt's doctoral student in Bonn and was in close contact with him later in Berlin. Moreover, their personal relationship is predominantly described with positive attributes. On this issue, however, one finds a certain vagueness in the literature by Schmitt scholars. Some write about their 'friendship relation' (Neumann 1981, 239) or their 'good friendship' (Koselleck 2019, 377) and leave it open whether the alleged friendship has lasted over Schmitt's involvement in the Nazi regime. Other authors are more explicit and suggest that Kirchheimer and Schmitt had a nearly lifelong-shared understanding that bridged their eminent political differences and insinuated a good personal relationship until a few years before Kirchheimer's early death. The editor of Telos, Gary S. Ulmen, who became a proponent of Schmitt's thought in the 1980s, stated the following, explicitly referring to Kirchheimer in his later years: 'There has been an important Jewish reception of Schmitt [...] let's face it: Critical Theory makes strange bedfellows' (cited in Zwarg 2017, 368). And to Jürgen Seifert, the friendly contact between the two after 1945 was an impressive testament to the fact that 'rejection of positions did not necessarily have to mean personal enmity' (Seifert 1985, 199).

This narrative is supported by the claim, considered verified by Seifert and others, that Kirchheimer had visited Schmitt at his home in Plettenberg several times. Such an assertion, however, is in stark contrast to Ellen Kennedy's statement in her famous article about Schmitt and the Frankfurt School in which she noted, based on information from a letter by George Schwab, that Kirchheimer had visited Schmitt only once in the late 1940s (Kennedy 1986, 392). Nevertheless, the claim that Kirchheimer had visited Schmitt multiple times can now be found in many scholarly contributions on Schmitt and Kirchheimer.

The original source for this assertion was Schmitt himself. In summer 1980, he had told Rainer Erd in an interview about numerous visits by Kirchheimer in Plettenberg. ${ }^{1}$ This piece

\footnotetext{
${ }^{1}$ Information by Rainer Erd in an e-mail to the author dated 24 March 2021.
} 
of information found its way into an article by Volker Neumann shortly after (Neumann 1981, 239). Since then, these alleged multiple meetings have become part of the biographical literature on Schmitt. Schmitt's best biographer, Reinhard Mehring, writes about Kirchheimer visiting Schmitt 'repeatedly' (Mehring 2014a, 432); for him Kirchheimer was the active part in the relationship between the two as he writes that in the end the supposed 'efforts of Otto Kirchheimer to have a renewed relationship to his old doctoral advisor from the period in Bonn failed' (Mehring 2018, 160; 2014b, 33, 137). Helmut Quaritsch, a right-wing proponent of Schmitt, used the story of several visits sardonically against a mentally 'unbalanced' (Quaritsch 1995, 74) Kirchheimer as evidence of his purported opportunism (Quaritsch 1995, 72). Joseph W. Bendersky speaks of Kirchheimer's 'return' to Schmitt, which had begun with his visits in 1947 (Bendersky 2016, 137). Rolf Wiggerhaus writes in his history of the Frankfurt School that 'Kirchheimer visited Schmitt on several occasions' (Wiggershaus 1995, 470). Dirk van Laak $(1993,135)$ follows him and mentions as well 'several visits' of Kirchheimer 'after 1949' in Plettenberg.

In the following, I am not going to discuss (again) the complex way in which young Otto Kirchheimer used elements of Schmitt's theory for his own left political project - this has been done already by numerous authors convincingly (cf. Scheuerman 1994; 1996; Söllner 1996; 2009; Schale 2006). I will neither demonstrate how Kirchheimer emancipated his political thought from Schmitt already in late 1930 and how he became an outspoken critique of his former doctoral supervisor at the end of the Weimar Republic (cf. Buchstein 2017). Instead, I will focus on two different issues concerning the relationship between Kirchheimer and Schmitt after 1945. First, with regard to the personal aspects of their relationship: Based mainly on unpublished archival findings as well as on personal communications I had on this issue in the past, ${ }^{2}$ I want to refute the tale that suggests a close personal relationship between Kirchheimer and Schmitt in the postwar era. Rather, Kirchheimer's position towards Schmitt became reserved, if not hostile. Second, I want to take a closer look at their substantial differences by demonstrating that Kirchheimer articulated a sharp criticism of the constitutional thought by Schmitt and his followers. Kirchheimer strongly attacked Schmittianism as his way to intervene in the German debate on constitutional theory. Late Otto Kirchheimer was no Left-Schmittian at all, just the opposite. His publications after 1945 on parliamentarism, transformations of political party systems, political justice, comparative politics and the waning of political opposition in Western democracies lack any Schmittian elements of thought (cf. Buchstein 2020b). One may hinge the image of Kirchheimer as a paradigm for LeftSchmittianism exclusively on his early work in the golden years of the Weimar Republic. But that viewpoint is incomplete because it ignores the learning process, which led Kirchheimer far away from the Schmittian theories he knew first hand. The development of Otto Kirchheimer's legal and political thought after 1945, in particular his criticism of Schmitt's earlier writings during the Weimar Republic, provides lessons still to be learned for those who praise Kirchheimer as a kind of godfather and patron of today's Left-Schmittianism.

\section{A Matter of Proud Self-Affirmation: The First Meeting in 1949}

The term 'Schmittianismus' was polemically used to characterize Kirchheimer's work in a German communist newspaper for the first time in the beginning of $1933 .^{3}$ This characterization overlooked that Kirchheimer had recognized Schmitt's participation in the destruction of the Weimar Republic already in 1930 and that he had begun to criticize some of the fundamentals of Schmitt's political and constitutional theories (Scheuerman 1994, 80-97;

\footnotetext{
${ }^{2}$ Namely with Ossip K. Flechtheim (1909-1998), Wilhelm Hennis (1923-2012) and John H. Herz (1908-2005).

${ }^{3}$ Unsere Zeit' as of 15 February 1933 (quoted in Schale 2006, 71).
} 
Schale 2006, 71-80; Buchstein 2017). Schmitt's diaries of the final Weimar years, which were published in 2010 for the first time, indicate how Schmitt reacted to these changes in his attitude towards Kirchheimer. At first, he praised Kirchheimer in his notes as a kind of wunderkind among his students. But when angered by Kirchheimer's incisive criticisms, he turned to antisemitic slurs about, as he wrote in a diary entry in 1932, the 'ugly Jew' (Schmitt 2010, 231).

The situation changed after the Nazi party took power. Kirchheimer lived in poor conditions in Paris and New York, whereas Schmitt made a career in the early years of the Nazi regime. Germany's defeat in World War II shifted the constellation between the two of them again. In what follows, I want to demonstrate how Schmitt calculated that he would benefit from trying to reconcile with Kirchheimer and how he manipulated accounts of their contacts to suggest that he had. What Schmitt tried to restore was his personal reputational interest: to render his own right-wing political theories more palatable and to downplay Kirchheimer's political thinking as a mere appendage of his own. A closer look at the original sources, however, indicates that Kirchheimer rejected Schmitt's overtures. Kirchheimer, who described Schmitt as a "man of darkness' ${ }^{4}$ in a letter to his colleague Ernst Friesenhahn in 1958, had long since matured into a fully independent thinker and was developing his own theory of modern parliamentary democracy, which is in direct contrast to Schmitt's political thought.

In 1958, Otto Kirchheimer was asked by Arvid Brødersen about his personal relationship with Schmitt and he replied in a letter: 'I neither saw C. S. in the period between 1932 and 1949 nor maintained any relations with him at all. After the war, when I was in Germany for the US State Department, I spoke with C. S. twice. 1949 and 1953.5 This statement can be verified in personal documents of both Schmitt and Kirchheimer. There was just one single visit of this kind shortly after the war, and the two only met one more time, namely in Cologne in 1953. In addition, compared with the correspondence they had with other colleagues and friends, the letters the two exchanged are meager even in terms of their quantity.

How did the two of them reconnect after 1945? The first personal conversation came about at Schmitt's initiative. Schmitt first sought to take up contact indirectly, through Ossip K. Flechtheim, a mutual acquaintance from their Weimar days. Flechtheim and Kirchheimer were acquaintances from the early 1930s; Flechtheim knew Schmitt from his time at the University of Cologne during the spring of 1933, when he had unsuccessfully tried to obtain his doctorate under him and had witnessed how Schmitt had seen to it that a Jewish assistant professor was fired. ${ }^{6}$ In his function as Lieutenant Colonel with the Office of the US Chief Counsel for War Crimes, Flechtheim had summoned Schmitt to Berlin for an interrogation by Robert Kempner, the Assistant US Chief Counsel for the Nuremberg Trials, in March 1947. ${ }^{7}$

\footnotetext{
${ }^{4}$ Letter from Otto Kirchheimer to Ernst Friesenhahn dated 15 December 1958. State University of New York, University at Albany, Special Collections \& Archives, Otto Kirchheimer Papers, Series 2, Box 2, Folder 61.

${ }^{5}$ Letter from Otto Kirchheimer to Arvid Brødersen dated 2 March 1958. State University of New York, University at Albany, Special Collections \& Archives, Otto Kirchheimer Papers, Series 2, Box 1, Folder 25. Kirchheimer knew Arvid Brødersen, who had studied sociology in Berlin, since 1929. Later they were colleagues at The New School for Social Research.

${ }^{6}$ As reported by Ossip K. Flechtheim in a conversation with the author on 13 February 1988 (cf. also Wieland 1986, 109). Born in 1909, Flechtheim had been detained in 1935 because he was a member of the socialist resistance group Neu Beginnen; he was then able to flee to Switzerland. He met Kirchheimer again in 1939 at Max Horkheimer's Institute of Social Research, and from then on, they remained good acquaintances, through Flechtheim's schoolmate John H. Herz. On Flechtheim's biography cf. Flechtheim/Joos (1991).

7 Letter from Ossip K. Flechtheim (Counsel for War Crimes) to Carl Schmitt on 17 March 1947. Landesarchiv Nordrhein-Westfalen, Papers of Carl Schmitt, RW 265-3681. Cf. also Wieland (1986, 101-103), Gross (2000, 342-344) and Bendersky (2007, 7-9) regarding Flechtheim's role.
} 
Schmitt was aware that Flechtheim knew Kirchheimer, for he inquired about Kirchheimer's fate and asked him to convey his best regards. ${ }^{8}$

One can only speculate about Schmitt's motives. After being released from prison in 1947 , Schmitt had found a place to stay in his hometown Plettenberg in the Sauerland region. He regarded his situation as precarious and suspected 'victors' justice' everywhere. He considered returning emigrés in particular to be responsible for his situation (Bendersky 2007). At the same time, he had not yet given up hope that he would be appointed to a chair again at a German university, like many other professors who had successful careers during the Nazi period. Thus, in the early postwar years, he kept abreast of the policies of filling positions at universities in the Western zones, casting his net widely. ${ }^{9}$ In this effort, his interest had turned to Kirchheimer again.

On 27 November 1949, two and a half years after Flechtheim had given him Schmitt's regards, Kirchheimer visited Schmitt in Plettenberg unannounced. There is little verified information about this meeting besides anecdotes Schmitt later circulated in his coterie. For example, Kirchheimer's doctoral advisor was said to have asked him at the door upon his arrival, 'Are you coming as a friend or a foe?' The reports do not include Kirchheimer's answer to this question, ${ }^{10}$ which was an allusion to Schmitt's famous book Der Begriff des Politischen (Schmitt 1963). There are two sources from Schmitt's side concerning this visit. The first is a letter from 29 November 1949 to his wife Duška, who at the time was receiving treatment in a clinic in Heidelberg. Schmitt wrote:

Day before yesterday, Sunday midday, a big yellow American car drove up, with 'USA' in bold letters. I thought I was going to be picked up [for interrogation or the like] once again. Anima opened the door. Who was there? I don't think, dear Duška, that you would guess. It was Otto Kirchheimer. Fat, but otherwise unchanged. We had a good conversation for $2 \frac{1 / 2}{2}$ hours, then he drove on to Düsseldorf. He works for the State Department in Washington and just wanted to see how I was doing. He was not satisfied with Ex Captivitate [Salus] because there was no explanation of what I did in 1933. I gave him the essay on [Francisco de] Vitoria. I enjoyed his visit. Incidentally, I don't believe it is very meaningful. It was simply a stirring of human interest in my fate, nothing more. But it was that, and in that sense, it was still nicer than the typical behavior of the German colleagues. ${ }^{11}$

Another source is a letter by Schmitt to Ernst Rudolf Huber, his former assistant professor in Bonn. It reads:

Do you remember Otto Kirchheimer' He is now with the State Department in Washington. When he visited me two weeks ago, he mentioned the conference of the Association of Constitutional Lawyers (Staatsrechtslehrertagung). We agreed that an outburst

\footnotetext{
8 Ossip K. Flechtheim in a conversation with the author on 13 February 1988.

9 On how Schmitt perceived the situation after 1945 and took up contacts in all directions cf. Mehring (2014a, 407-430).

${ }^{10}$ Cf. on this anecdote Söllner $(1996,114)$.

11 Letter from Carl Schmitt to Duška Schmitt dated 29 November 1949, from Schmitt's papers. Author thanks Gerd Giesler for pointing out this source, which has not been published to date, and for making it available. Landesarchiv Nordrhein-Westfalen, Papers of Carl Schmitt, RW 265-29926/46. The essay on Vitoria is Schmitt's anonymous article Francisco de Vitoria und die Geschichte seines Ruhmes (Francisco de Vitoria and the History of His Fame) in the July 1949 issue of the journal Die neue Ordnung, which is published by Dominicans. In it, Vitoria is presented as a precursor of modern international law, which also grants full rights to peoples which are not Christian. Schmitt incorporated this text in Nomos der Erde.
} 
of intellectual freedom and dégagé thinking as sublime as the one we experienced in $1930 / 32$ is hardly to be expected again. ${ }^{12}$

It is not easy to establish Kirchheimer's intention in visiting Schmitt based on what the latter reported on it in two letters. Was it primarily 'a stirring of human interest' in the fate of his doctoral advisor, as the latter reported? Or was Kirchheimer mainly interested in knowing how Schmitt thought about his own, important role in establishing the Third Reich in its early phase after its demise? Did he want to take up the opportunity to discuss this directly and in person with Schmitt? Was he primarily concerned with criticizing Schmitt's complete failure to grapple with his role in the Nazi regime in his brief book Ex Captivitate Salus, which had been published a few weeks before? Kirchheimer was not the only one who read Schmitt's book as a document of stubbornness und unwillingness to reflect upon his actions. ${ }^{13}$ Or did he have a different motive that had less to do with his personal interest in Schmitt and more with himself? Almost 10 years later, Kirchheimer wrote the following in his letter to Arvid Brødersen: 'When he [Schmitt] attempted to justify his behavior, I told him, as early as 1949, that the authority to judge what he had told me about could only be his conscience. ${ }^{14}$ According to this letter the two also talked about a brochure Kirchheimer had written in 1935 and which had been illegally distributed under a pseudonym and in the design of a series of Schmitt's that was widely read in the German Reich. ${ }^{15}$

But there is another, second-hand source about the visit that may represent Kirchheimer's view. Kirchheimer spoke with Wilhelm Hennis in the 1960s a few times about visiting Schmitt. Concerning the external circumstances, what Hennis recounted more than 50 years later after Kirchheimer had told him, ${ }^{16}$ corresponds to what Schmitt wrote to his wife. According to Hennis, Kirchheimer had read Schmitt's Ex Captivitate Salus and was outraged by Schmitt's unwillingness to grapple self-critically with his own responsibility for the Nazi regime's policies. When he stopped by in Plettenberg, he had wanted to demonstrate to Schmitt the extent to which the political tide had turned, appearing in the uniform of a member of the American occupying forces ${ }^{17}$ and a big car driven by a chauffeur. He had also wanted to show that he, who in 1933 had been one of those whom Schmitt had wanted to see driven out of Germany once and for all in his Nazi propaganda writings, had succeeded in surviving, and in a dual sense: as a Jew and as a leftist. He had weathered being persecuted by the Nazi regime and had now come back to his old home country as a US citizen and in an important position serving the State Department. According to Hennis, whose memories were permeated with highly interpretive elements, Kirchheimer considered his visit to Plettenberg first and foremost a sign of 'proud self-affirmation' ('stolze Selbstbehauptung') vis-à-vis his former doctoral advisor. ${ }^{18}$

Schmitt, however, stuck to his attitude. Shortly after the visit, he considered his antisemitism and his hatred of the returning emigrés validated once again in his personal notes. A few weeks after Kirchheimer's visit, on 12 January 1950, Schmitt entered the following in his Glossarium:

\footnotetext{
12 Letter from Carl Schmitt to Ernst Rudolf Huber dated 10 December 1949. In: Schmitt/Huber (2014, 355).

13 For the critical comments by Ernst Niekisch see van Laak $(1993,78)$.

${ }^{14}$ Letter from Otto Kirchheimer to Arvid Brødersen dated 2 March 1958. State University of New York, University at Albany, Special Collections \& Archives, Otto Kirchheimer Papers, Series 2, Box 1, Folder 25.

15 On this incident see Luthardt (1976) and Neumann $(2015,391)$.

16 Wilhelm Hennis recounted this in a conversation with the author on 26 September 2009.

17 The fact that Kirchheimer appeared in an American uniform was also reported by Ernst Hüsmert, the administrator of Schmitt's estate, cf. email from Reinhard Mehring to the author dated 10 March 2019.

18 Wilhelm Hennis chose these words in the conversation with the author on 26 September 2009.
} 
When we began to disagree, the Jews sub-introduced..$^{19}$ Today, these people who had sub-introduced themselves are experiencing restoration with colossal claims for restitution and repayments. But still, the sub-introduced are even worse than the returning emigrés who relish their revenge. They should be ashamed of accepting the dollar (Schmitt 2015, 221).

Shortly thereafter, he noted about the returning emigrés: 'Those who did emigrate are declaring those who did not to enemies of the country' (Schmitt: 2015, 226). Schmitt did not waver in his abhorrent antisemitic position for the rest of his life. ${ }^{20}$

\section{Distant Distance: Correspondence and Another Meeting}

The surprise visit in Plettenberg did not revive the close, almost friendly relationship between the two from the late 1920s. On the contrary, that Kirchheimer had broken off their relationship in the early 1930s could no longer be patched up but only papered over in sporadic written exchanges with friendly words and some 'obligatory letters' milestone birthdays. The surviving correspondence between both and things they told third parties make it possible to trace the further development of the relationship between the two quite precisely, at least in its contours. ${ }^{21}$

After the visit, they were not in contact for more than two and a half years. In the spring of 1952, Schmitt took the initiative again and sent a copy of a legal opinion he had prepared for the Buderus-Röchling steelworks, which sought to take action against its partial expropriation by the State Government of Hesse. ${ }^{22}$ Kirchheimer could potentially have been interested in the topic since he had published a book and a few articles on the topic of expropriation during the Weimar Republic. When he responded on 4 May 1952, Kirchheimer first expressed his condolences on the death of Schmitt's wife Duška, who had passed away 5 months before. He went on to thank Schmitt for sending the legal opinion to Washington. However, he commented critically that he could not 'fully agree with your differentiation between expropriation through law that was still permissible and [...] expropriation through reinterpretation of the constitution, which was not permissible.' This was the main point of Schmitt's line of argument to avoid expropriation, which did not succeed in the trial (Neumann 2015, 524527). Kirchheimer was more positive about Schmitt's book Nomos der Erde, which was published in 1950. He had read it 'with great pleasure' and closed the letter with the prospect of exchanging views about these topics in a personal conversation if the opportunity arose. ${ }^{23}$

Schmitt responded shortly afterwards, seeking to discuss the role of the Federal Constitutional Court in the legal and political system of the young Federal Republic with Kirchheimer. But he did not respond to the question for 3 months and with a few lines only. In the meantime, the court had rejected the claims of the Buderus steelworks. He commented favorably on the Federal Constitutional Court and informed Schmitt of the following:

I sometimes look at the decisions from Karlsruhe [the seat of the Federal Constitutional Court]; since the legislature did not give much thought to the inherent limits of constitutional jurisdiction when delineating them, the court has to take care not to reduce its entire jurisdiction to absurdity.

${ }_{19}$ The verb 'subintroduzieren', which Schmitt uses here, does not exist in German. In this particular context, and used by Schmitt, it can be assumed to mean: 'to come in and assume a leading position in place of us.'

20 On Schmitt's aggressive antisemitism and his hate against Jewish émigrés in particular see Gross (2016).

${ }^{21}$ So far only Mehring $(2007,65-68)$ has reported on parts of the correspondence in Schmitt's papers.

22 Later published as Rechtsstaatlicher Verfassungsvollzug in his Verfassungsrechtliche Aufsätze (Schmitt 1958, 452-488).

${ }^{23}$ Letter from Otto Kirchheimer to Carl Schmitt dated 4 May 1952. Landesarchiv Nordrhein-Westfalen, Papers of Carl Schmitt, RW 265-7598. 
He closed the letter by mentioning the prospect, raised by Schmitt, that a personal meeting might be possible in late 1952 or early 1953 despite his extensive travels in Europe. ${ }^{24}$ Kirchheimer's longest letter to Schmitt is from late November 1952. It is another response to a letter from Schmitt. In a friendly and courteous tone, Kirchheimer expressed fundamental criticism of Schmitt and those of his students who were constitutional lawyers in West Germany. Looking back on his essay Bemerkungen zu Carl Schmitts 'Legalität und Legitimität', which he had authored with Nathan Leites for the 'Archiv für Sozialwissenschaften und Sozialpolitik' exactly 20 years before, he wrote Schmitt:

You will remember that even in my co-authored essay from 1932 on legality \& legitimacy, I tried to confront the conceptual realism with the actual tendencies of institutional development; that does not meet the internal consistency of your train of thought, but it may well shift the perspective somewhat. ${ }^{25}$

Kirchheimer directed his criticism at some of Schmitt's students as well:

When reading [Werner] Weber's little book, it became clear to me again that critical engagement with the conceptual structure of constitutional theory, which Weber took aboard in toto, is overdue; what a pity that there doesn't seem to be anyone in Germany who is taking on such fruitful work; although German constitutional theory, to the extent that it exists intellectually, relies completely on your body of thought, it would benefit more from it if it complemented the act of receiving ideas with critical reception. ${ }^{26}$

Concerning Ernst Forsthoff, he let Schmitt know that he had read Forsthoff's paper on the position of the political parties in terms of constitutional law, but had strong doubts that Forsthoff did justice to the topic in the 20th century with his skepticism with regard to political parties. ${ }^{27}$ In all these points, Kirchheimer was fundamentally concerned with the relationship between Schmitt's general theoretical approach and the empirical 'question of historical reality', which he believed was fully disconnected. Kirchheimer had written the letter by hand on American Christmas-themed paper, embellished with some kitschy Catholic Renaissance angels. It animated Schmitt to note ironically 'Kirchheimer!' on it; he apparently found it inappropriate and typical for Kirchheimer to use a letter of Christmas greetings for a critical statement on political theory.

A year before Schmitt's 65th birthday in the summer of 1953, the editors of a planned Festschrift invited Kirchheimer for a contribution. He rejected the request, together with Ernst Friesenhahn. He explained his decision to Arvid Brødersen by noting that he sought to avoid the appearance of contributing to publicly enhancing Schmitt's reputation among German constitutional theorists. ${ }^{28}$ Meanwhile, Schmitt had sent him Lilian Winstanley's book Hamlet and the Scottish Succession, which his daughter had translated into German and for which Schmitt had written a brief preface, for Christmas in 1952. Kirchheimer thanked

\footnotetext{
${ }^{24}$ Letter from Otto Kirchheimer to Carl Schmitt dated 8 September 1952. Landesarchiv Nordrhein-Westfalen, Papers of Carl Schmitt, RW 265-7599.

25 This quote and the following ones are from the handwritten letter from Otto Kirchheimer to Carl Schmitt dated 21 November 1952. Landesarchiv Nordrhein-Westfalen, Papers of Carl Schmitt, RW 265-7600.

26 This refers to Weber's book Spannungen und Kräfte im westdeutschen Verfassungssystem, cf. Weber (1951).

${ }^{27}$ In it, Forsthoff calls for party office and parliamentary mandate to be made incompatible, among other things, cf. Forsthoff (1950, 23f.).

${ }^{28}$ Cf. letter from Otto Kirchheimer to Arvid Brødersen dated 2 March 1958. State University of New York, University at Albany, Special Collections \& Archives, Otto Kirchheimer Papers, Series 2, Box 1, Folder 25.
} 
him on 28 January 1953 without going into Schmitt's peculiar interpretation of the theme of Hamlet. ${ }^{29}$ He contacted Schmitt again in February 1953 from the residence of Richard Schmid, the president of Stuttgart's Oberlandesgericht (Higher Regional Court). He would be in his vicinity professionally, presumably in April or May, and would give Schmitt a telephone call to arrange a meeting, should the occasion arise. ${ }^{30}$ In late March, he wrote to him again, suggesting they meet in Düsseldorf. ${ }^{31}$ They did finally meet for a few hours in Cologne in April 1953; Schmitt was accompanied by his daughter Anima. No documents seemed to have survived with regard to this encounter. But apparently, neither side was particularly pleased with it, for with the exception of a terse letter from Kirchheimer for Schmitt's 65th birthday, which reads as if he was merely going through the motions, ${ }^{32}$ they had no contact at all for the next 5 years. ${ }^{33}$

\section{Criticizing Schmittianism in German Legal Thought}

Kirchheimer articulated his criticism of Schmitt and his students not only in letters, but also in smaller publications, most of them book reviews. This was his way to intervene in the German debate on constitutional theory. ${ }^{34}$ The first one was a review of Werner Weber's 1951 book Spannungen und Kräfte im westdeutschen Verfassungssystem for the American Political Science Review. In 1948, Weber had accepted an appointment to a chair for public law in Göttingen. Rudolf Smend, who would have liked Kirchheimer to be appointed instead, expressed his concern with regard to his new colleague in Göttingen because of his close ties with Schmitt. ${ }^{35}$ Kirchheimer shared this concern and told Smend about the review he intended to write about Weber's book. He summarized the essence of the review with the words: 'I do not think it is very productive to deal with the current circumstances in Germany using Carl Schmitt's scarcely modified conceptual framework from the years $28-32 .{ }^{36}$ Moreover, he agreed with Smend that '[Hermann] Heller is more productive than C.S. in the long run.' ${ }^{37}$ In April 1952, he asked Smend to hand the text of his then completed review over to Weber 'with a fitting remark $^{\prime 38}$ so that, in all fairness, Weber would not find out about it only indirectly once it had been published in the United States.

The review of Weber's book is a frontal attack. Although the author was an 'intelligent and lucid writer' (Kirchheimer 1951, 220), he remained hopelessly caught in the 'conceptual framework erected by Carl Schmitt in the late twenties and the early thirties' (p. 220) in his

${ }^{29}$ Letter from Otto Kirchheimer to Carl Schmitt postmarked 28 January 1953. Landesarchiv Nordrhein-Westfalen, Papers of Carl Schmitt, RW 265-7601. In his preface to the book, Schmitt had made a connection between the 'theatricalization of one's own historical being' in Shakespeare's play and the events of the 1934 'Night of the Long Knives.'

30 Letter from Otto Kirchheimer to Carl Schmitt [no date; February 1953]. Landesarchiv Nordrhein-Westfalen, Papers of Carl Schmitt, RW 265-7593.

31 Letter from Otto Kirchheimer to Carl Schmitt dated 28 March 1953. Landesarchiv Nordrhein-Westfalen, Papers of Carl Schmitt, RW 265-7594.

32 Letter from Otto Kirchheimer to Carl Schmitt dated 1 July 1953. Landesarchiv Nordrhein-Westfalen, Papers of Carl Schmitt, RW 265-7602.

33 Schmitt mentioned to Winfried Martini in September 1953 that he wanted to ask Kirchheimer about the whereabouts of sociologist Heinz Otto Ziegler, who had emigrated to the United States (cf. Burkhardt 2013, 123) - yet nothing is to be found in the relevant archives relating to this question.

34 On the general development of these debates see Frick (2019).

35 Letter from Otto Kirchheimer to Rudolf Smend dated 9 June 1951. Staats- und Universitätsbibliothek Göttingen, Papers of Rudolf Smend, Cod. Ms. R. Smend, Briefwechsel Kirchheimer.

${ }^{36}$ Letter from Otto Kirchheimer to Rudolf Smend dated 1 February 1952. Staats- und Universitätsbibliothek Göttingen, Papers of Rudolf Smend, Cod. Ms. R. Smend, Briefwechsel Kirchheimer.

37 Letter from Otto Kirchheimer to Rudolf Smend dated 25 October 1951. State University of New York, University at Albany, Special Collections \& Archives, Otto Kirchheimer Papers, Series 2, Box 2, Folder 19.

38 Letter from Otto Kirchheimer to Rudolf Smend dated 1 April 1952. Staats- und Universitätsbibliothek Göttingen, Papers of Rudolf Smend, Cod. Ms. R. Smend, Briefwechsel Kirchheimer. 
efforts to analyze the political system of the Federal Republic. Readers of the book encountered all of their common doctoral advisor's 'old clichés' (p. 220): the incontestable authority of the state, a strong and neutral executive branch, an elite at the head of state administration and criticism of pluralism of political parties as well as of the political influence of interest groups. Kirchheimer commented sarcastically that in hindsight, the Weimar Constitution suddenly came off as not all that bad in Weber's tract but only to attack the newly established system of the Federal Republic more vehemently.

Kirchheimer countered Weber's charge with regard to misguided perfectionism of the Basic Law by pointing out that Weber had blocked his own ability to realistically assess the functioning of the West German system because of his Schmittian conceptual framework. Weber's 'complete acceptance of Carl Schmitt's conceptual framework and scale of values has stood in the way of a dispassionate analysis of the interplay between constitutional order and the social reality of the Bonn state' (p. 220). Neither his excessive criticism of the status of the political parties in the Basic Law nor of the federal order laid down in the Basic Law was convincing, Kirchheimer claimed. Contrary to Weber's reiteration of the old clichés, Kirchheimer described the parties as the primary agencies of political integration whose legitimacy 'rests in their ability to channel the political and social energies of their clientele of unions, economic associations or churches into political action' (p. 221). For this reason, it was to be considered positive that they were mentioned explicitly in the German constitution, the Basic Law.

Three years later, Kirchheimer attacked Ernst Forsthoff, the most prominent Schmittian in Germany, in his essay Parteistruktur und Massendemokratie in Europa (Party Structure and Mass Democracy in Europe) published in the Archiv des öffentlichen Rechts in 1954. Kirchheimer bluntly rejected Forsthoff's proposal to shield parliamentary party groups from the influence of their party leadership by making it legally incompatible to belong to a parliament and simultaneously hold a party office (Forsthoff 1950). Such a proposal was based on the 'mistaken assumption' (Kirchheimer 1954a, 241) that it was only the parliamentary party group, not the entire party, that was tasked to design policy. If differences between authorities of the parliamentary party groups and the parties themselves arose in current-day parliamentary democracies, this was a clear indication of deeper social and political discrepancies. These would be resolved through splits between parliamentary party groups and the headquarters of political parties and the establishment of new ones, which did not require restrictions by the state.

Kirchheimer's review of the book Wirtschaftsverwaltungsrecht by Ernst Rudolf Huber, a third student from Schmitt's circle in Bonn, of the same year was a bit more moderate. ${ }^{39}$ However, Kirchheimer diagnosed a certain Schmittian intellectual legacy in Huber's writings too, describing his 'continuing belief in the possibility of a neutral state with the functions of an arbitrator' (Kirchheimer 1954b, 267) and criticizing, as a consequence of this, the antitrade union tendency of such convictions. At the same time, Kirchheimer saw the fact that the Basic Law was indeterminate in terms of economic policy, which Huber championed, as somewhat problematic for the author since he refrained from working through the various, and partially competing, imperatives of constitutional law in the context of their 'proving themselves over the course of history' (p. 268). Instead, Huber took refuge in conceptual arguments without asking himself 'to what extent any correspondence exists between the conceptual schema and social reality' (p. 269).

${ }^{39}$ On Huber's relationship with Schmitt see Mehring (2017, 151-181). 
In the summer of 1956, Kirchheimer again picked a fight with a student of Schmitt's, this time of the younger generation, in a review for the Archiv des öffentlichen Rechts. His discussion of Joseph H. Kaiser's book Die Repräsentation organisierter Interessen (The Representation of Organized Interests) was completely different. At the very beginning, Kirchheimer criticized Kaiser's methodological approach. Instead of seeking orientation in 'empirical social research, which is being conducted in the Anglo-American and increasingly also in the Romance cultural region' (Kirchheimer 1956, 271), and instead of limiting his work, as Huber did, to legally classifying societal phenomena according to the constitutional order as objectively as possible, Kirchheimer alleged that Kaiser wove 'rich material from the history of ideas and contemporary history into a predetermined conceptual schema, persistently adopting Carl Schmitt's ways of thinking and forms of presentation' (p. 271). Kaiser's argument, he stated, was based on a 'concept of the political rooted in the antinomy of state and society' (p. 271) that, when discussing the role of societal interest groups, unavoidably arrived at the hypothesis that pressure groups undermined the character of the state institutions, which alone were representative.

Towards the end of his critique of Kaiser, Kirchheimer provided insight into his own, skeptical view of the role of the individual in modern society. If Kaiser was calling for a strong state because it alone could protect individuals from excessive claims by intermediary institutions, Kirchheimer had a more 'ambivalent' view (p. 275). States as well as interest groups could 'easily and almost unnoticeably' (p. 274) make service provision and protection become intertwined, as well as harassment and oppression. The best protection of the individual, he claimed, consisted in exploiting organizational rivalries and spaces between institutions. It was hardly surprising in the current 'lull of the postfascist age and in the neighborhood of the Bolshevist sphere' (p. 275) that many people sought to elude being organized by the state and in interest groups. This was the reason why Kirchheimer countered Kaiser's argument for a strong state with the point 'that the individual, the state, and the societal apparatus were to work together sufficiently' (p. 275).

In 1957, Kirchheimer discussed Kaiser's book about interest groups again in his essay The Political Scene in West Germany. The article was originally published in World Politics. This time, he used his criticism to grapple explicitly with Carl Schmitt, and in this context, he praised Peter Schneider's book on Schmitt titled Ausnahmezustand und Norm, which was forthcoming (Schneider 1957). Peter Schneider's study had been supervised by Friesenhahn as his habilitation dissertation after he had lost Carlo Schmid in Tübingen in this role and 'Hans Schneider [...] had caused him difficulties because of the habilitation dissertation.' ${ }^{40}$ Schneider sent a copy of the proofs to Kirchheimer, who was interested in them. When Kirchheimer had finished reading, he wrote Friesenhahn that the book 'stuck too closely to the material' at first, but that after a good 60 pages, 'the book becomes first-rate.' He hoped it would be widely read in Germany. ${ }^{41}$

Kirchheimer was full of praise for Schneider's monograph as he saw it as indication that the culture in the legal sciences in Germany was changing for the better. Schneider's book was 'one of the most encouraging signs on the German intellectual horizon' (Kirchheimer 1957, 348). 'In its long-range literary impact', Kirchheimer continued, 'it may be presumed to overshadow much of present-day writing' (p. 348). With admirable energy, Schneider had dared to draw a coherent and comprehensive picture of Schmitt's theory based on his many

\footnotetext{
40 Letter from Ernst Friesenhahn to Otto Kirchheimer dated 4 February 1955. State University of New York, University at Albany, Special Collections \& Archives, Otto Kirchheimer Papers, Series 2, Box 1, Folder 55.

${ }^{41}$ Letter from Otto Kirchheimer to Ernst Friesenhahn dated 10 March 1957. State University of New York, University at Albany, Special Collections \& Archives, Otto Kirchheimer Papers, Series 2, Box 1, Folder 61.
} 
writings, thus providing the background for a detailed analysis of discrepancies in Schmitt's theories and imprecisions in his concepts. Kirchheimer agreed with Schneider's basic interpretive hypothesis: In Schmitt's theory, the bourgeois state governed by the rule of law was the 'eternal enemy' (p. 349). Kirchheimer's brief review of Schneider's book includes almost the entire list of his own key criticisms of Schmitt in compact form:

The lack of any clear-cut criteria for differentiating between nomos and violence, the discrepancy between the traditional liberal concepts of classical international law and the decisive rejection of an artfremd and disintegrating liberalism as part of the domestic constitutional order, the brooding omnipresence of the people's constituent power and its incapacity to act as a constituted organ, the indeterminate character of the values underlying concrete decisions, and the conjunction of a relativistic openness to a variety of historical interpretations with an ever-present negation of the rule of law (p. 348).

Peter Schneider was delighted about Kirchheimer's praise. He had thought that his harsh criticism of Schmitt had jeopardized his opportunities for an academic job in law in West Germany ${ }^{42}$ The fact that Kirchheimer used such clear words to publicly take a position against Schmitt and his students in German constitutional law was because of his fundamental conviction about how to engage with political opponents. In this matter, he wrote Brødersen in 1958:

I still think today that nobody should be held criminally or pseudocriminally responsible for their writings or their intellectual production. To a writer, the authority is the reaction of the audience and their own conscience. The question of employment sanctioned and paid for by the state is of course a different matter. ${ }^{43}$

\section{The Conflict over George Schwab's Dissertation}

It was Kirchheimer who started the direct communication with Schmitt after a 5-year pause. In July 1958, he wrote a few hurried lines on the letterhead of a hotel in Copenhagen to congratulate Schmitt belatedly on his 70th birthday and his daughter's wedding. ${ }^{44}$ Kirchheimer had again refused to contribute to the Festschrift for this occasion. Schmitt immediately picked up the ball and sent Kirchheimer a long letter. He reported in detail about his work from the previous year on the edition of his anthology Verfassungsrechtliche Aufsätze aus den Jahren 1924-1954 (Schmitt 1958). He emphasized to Kirchheimer that his writings from the Weimar period were as topical as ever: 'Because of the events in recent months (de Gaulle in France ... and the referendum in the Federal Republic) the old essays from 1932 have become more current than my new remarks from 1957.' In this letter, he also mentioned that he had had a visitor from New York in his hometown Plettenberg. Schmitt described him to Kirchheimer with the following words:

42 Letter from Peter Schneider to Otto Kirchheimer dated 9 February 1957. State University of New York, University at Albany, Special Collections \& Archives, Otto Kirchheimer Papers, Series 2, Box 2, Folder 1. Horst Ehmke was more critical of Schneider's book and expressed his fears to Kirchheimer as follows: 'I am not at all sure whether in our situation, the book might have the effect of being propaganda for Carl Schmitt.' Letter from Horst Ehmke to Otto Kirchheimer dated 19 May 1957. Friedrich-Ebert-Stiftung, Archiv für soziale Demokratie, Horst Ehmke Depositum, No. 504.

43 Letter from Otto Kirchheimer to Arvid Brødersen dated 2 March 1958. State University of New York, University at Albany, Special Collections \& Archives, Otto Kirchheimer Papers, Series 2, Box 1, Folder 25.

${ }^{44}$ Letter from Otto Kirchheimer to Carl Schmitt dated 25 July 1958. Landesarchiv Nordrhein-Westfalen, Papers of Carl Schmitt, RW 265-7603. 
I had a visit for some months in the summer from a young student from New York, George Schwab, Columbia University, with whom I had very good conversations and whom I found very friendly. If you ever have the opportunity to speak to him-his teacher is Herbert A. Deane-Public Law and Government, Columbia Univ.-the author of the book on H. J. Laski-I would be interested in your impression of him. ${ }^{45}$

Schmitt apparently believed that Kirchheimer would also be impressed by the young student from New York and support him. Kirchheimer did respond to the letter but only briefly one month later. Concerning Schmitt's visitor from New York, he wrote: 'I do not know Mr. Schwab yet, but will try to get in touch with him when the semester has begun. ${ }^{46}$ He brusquely rejected Schmitt's claim that his writings from the Weimar period were still as topical as ever: 'I do not believe in the repetition of similar situations; too many qualitative changes have taken place.' Nonetheless, Schmitt sent him a copy of his Verfassungsrechtliche Aufsätze for Christmas 1958 at the end of the year. ${ }^{47}$ Kirchheimer responded with a reprint of his essay France from the Fourth to the Fifth Republic (Kirchheimer 1958), ${ }^{48}$ which had just been published and which entailed an assessment of the events in France diametrically opposed to Schmitt's praise of the strong presidential system (Schale 2006, 309-314).

In the new edition of Verfassungsrechtliche Aufsätze, Schmitt had added appendices, some of them extensive, to all his old essays. In these comments to his own work, he mentioned some of the more recent writings by Otto Kirchheimer multiple times, all of them quoted in a manner that served to support his own remarks. Of Kirchheimer's newer works, Schmitt first and foremost used the 1957 essay Vom Wandel der politischen Opposition in which Kirchheimer claims that most modern democracies lack a true opposition. Schmitt used this hypothesis as evidence for his diagnosis that the state had become unable to act and that party cartels had taken overpower in Western democracies. ${ }^{49}$ Kirchheimer did not send a comment to Schmitt with regard to the book. After re-reading the essays and appendices, however, he expressed his criticism to Ernst Friesenhahn:

I have Schmitt's essays here, the man is intransigent and the relation between the reality of the concept and responsibility is as unclear to him today as it was 30 years ago. But I fear that the evil lies deeper than the harm that the most brilliant German political thinker since Max Weber could cause. It lies in the entire German attitude that is never willing to take stock of how political and conceptual formulations correspond to reality-I know, it resulted in my having the opposite tendency of not asking deeply enough about the values and going home reassured when I established what the political-sociological equation of a concept and [a] legal construct look like, but the former deplorable custom is simply much more at home in Germany. ${ }^{50}$

45 Letter from Carl Schmitt to Otto Kirchheimer dated 6 August 1958. State University of New York, University at Albany, Special Collections \& Archives, Otto Kirchheimer Papers, Series 2, Box 2, Folder 12.

${ }^{46}$ Letter from Otto Kirchheimer to Carl Schmitt dated 4 September 1958. Landesarchiv Nordrhein-Westfalen, Papers of Carl Schmitt, RW 265-7604.

${ }^{47} \mathrm{He}$ added a handwritten dedication: 'For Otto Kirchheimer as a greeting for Christmas from Carl Schmitt, 20/12/58.' Carl Schmitt, Verfassungsrechtliche Aufsätze. In: State University of New York, University at Albany, Special Collections \& Archives, Otto Kirchheimer Papers, Series 8-9, Box 5.

48 With the dedication 'With best wishes and thanks for the book! Your OK.' On the first page, Schmitt underlined the wording 'friends and foes.' Landesarchiv Nordrhein-Westfalen, Papers of Carl Schmitt, RW 265-25656.

${ }^{49}$ Cf. Schmitt (1958: 262, 346, 366 and 488). In a March 1960 letter to Rüdiger Altmann, Schmitt referred to this essay of Kirchheimer's in terms of the grand coalition in Austria and its prospects in Germany (cf. Burkhardt 2013, 155).

${ }^{50}$ Letter from Otto Kirchheimer to Ernst Friesenhahn dated 15 December 1958. State University of New York, University at Albany, Special Collections \& Archives, Otto Kirchheimer Papers, Series 2, Box 2, Folder 61. 
He did not mention how Schmitt had cited his own work on opposition. It is striking that from then on, Kirchheimer tried to avoid investing his time and labor in grappling with Schmitt and his students again. When Otto Stammer from Berlin asked him in January 1959 whether he would review Jürgen Fijalkowski's book on Schmitt, which had just been published at the IfPW, he declined without reading it first: 'Please forgive me, but there are many reasons why I would not like to deal with Carl Schmitt academically. ${ }^{51}$ He did not write any more reviews on new works by Forsthoff, Huber, or Kaiser, either. In the meantime, in February 1959, Schmitt warmly recommended reading Kirchheimer's Weimar ... und was dann? to young scholars from the left like Jürgen Seifert who contacted him. ${ }^{52}$

Nonetheless, the correspondence between Kirchheimer and Schmitt did not break off entirely. It did, however, take on the nature of smaller jabs, as the topics of the writings they exchanged reveal. In May 1959, Kirchheimer sent a reprint of his essay The Administration of Justice and the Concept of Legality in East Germany to Plettenberg, which includes a defense of the bourgeois state based on the rule of law in the face of those condemning it (Kirchheimer 1959). ${ }^{53}$ In March 1960, Schmitt in turn mailed a copy of the brochure Die Tyrannei der Werte, (Schmitt 1960) which had been published with a small print run of 200 private copies, with the dedication 'for Otto Kirchheimer, C.S.-20/3/60.'54

George Schwab, Schmitt's visitor from New York, was the trigger that escalated the dispute between Kirchheimer and Schmitt culminating in a complete severance of their communication. With Carl Joachim Friedrich acting as liaison, Schwab, who had been studying at Columbia University since 1954, initiated contact with Schmitt by visiting him in Plettenberg in June 1957. During this meeting, he decided to write his doctoral dissertation on Schmitt. Once Schmitt realized that he could impress Schwab with his ex post facto views about his own role at the end of the Weimar Republic, he too was delighted by his visitor and his plan. Schwab's dissertation supervisor at Columbia University was Herbert L. Deane, professor of political theory, who admittedly had never heard of Schmitt, let alone read anything by or about him. This was also true of his colleagues at the department. In 1959, Schwab visited Schmitt again for two months, and the two discussed the hypotheses in his dissertation about Schmitt's work and his impact from 1930 to 1936. When Kirchheimer had sounded out his chances for potentially leaving The New School for Social Research for a position at Columbia University, Deane suggested that Schwab should have close discussions with Kirchheimer. The two subsequently had some cursory conversations. Kirchheimer joined the five-person dissertation committee at Deane's request.

In October 1960, Schwab presented a draft of his dissertation to the committee. According to his report of this episode, the defense was initially 'boring's5 until Kirchheimer weighed in. He criticized the work fundamentally. Schwab had 'failed to understand Schmitt's true role in Weimar', he had 'turned Schmitt upside down' and had 'written an apology of Schmitt. 56 Kirchheimer also accused Schwab of incorrectly interpreting the principle of equal opportunity in the constitution. Finally, he criticized Schwab's fundamentally flawed understanding

51 Letter from Otto Kirchheimer to Otto Stammer dated 29 December 1959. State University of New York, University at Albany, Special Collections \& Archives, Otto Kirchheimer Papers, Series 2, Box 2, Folder 24 (cf. Fijalkowski 1958).

52 As reported by Jürgen Seifert, cf. Seifert $(1996,118)$.

53 Landesarchiv Nordrhein-Westfalen, Papers of Carl Schmitt, RW 265-25663.

${ }^{54}$ Carl Schmitt, Die Tyrannei der Werte. In: State University of New York, University at Albany, Special Collections \& Archives, Otto Kirchheimer Papers, Series 8-9, Box 5.

55 Schwab (1988a: 80). Unfortunately, it was impossible to find any files on the matter in Columbia University's archive.

56 These three quotes of Kirchheimer's words are to be found in Schwab $(1988 \mathrm{a}, 80)$ as he looked back on the events, cf. also Richter (2001, 222-224) and Hitschler (2011, 19-21). 
of Article 48 of the Weimar Constitution. This incorrect interpretation had resulted in a catastrophic codification of the state of emergency in Schwab's work. Kirchheimer explained in this context that Schmitt had paved the way for the Nazi regime with his theory of the state of emergency. ${ }^{57}$ As the other members of the committee had nothing substantive to contribute to the debate, they followed Kirchheimer's assessment; Deane knew Kirchheimer from other discussions and valued his knowledge and judgment. Schwab was instructed to thoroughly revise his work, to include various publications of Schmitt's from 1932 to 1936 that he had not yet considered and to engage with relevant newer secondary literature.

Schwab indignantly reported to Schmitt what had happened and initially considered submitting an application to the president of Columbia University to have Kirchheimer removed from the committee for lack of impartiality, ${ }^{58}$ but cast aside the idea because it had no prospect of success. Kirchheimer did not take the dispute about Schwab's work lightly, either. He correctly assumed that Schmitt had been involved much more than had been visible from the outside to make another attempt at rehabilitation via the US Kirchheimer reported about the matter one month later to Ernst Friesenhahn, asking him to keep the information to himself:

One of the first doctoral researchers who arrived at Columbia with a finished thesis was Mr. Schwab. He wanted to enlighten the world in American English about Carl Schmitt's life and works, the young man had sat at CS's feet and in fact had let himself be talked into believing that CS had actually always wanted to help the Weimar Constitution be protected and correctly applied, a kind of democrat in dire times, he was very discomfited when I announced that I would not accept his stupid scribblings, not even if modified, that as far as I was concerned, he could defend CS lock, stock, and barrel, but only if he emphasized his real doctrines and not disguised him as a democrat and strict constitutionalist. CS had also made his correspondence file available to him, and he came to me with transcripts of letters, including approval from the other side, from Franz Neumann, on legality and legitimacy. ${ }^{59}$

Kirchheimer and Schmitt exchanged letters briefly in the summer of 1961 while the conflict with Schwab was already smoldering. Kirchheimer asked where Schmitt would spend the summer and closed with the friendly phrase: 'I would be pleased if there might be the opportunity to see you again. ${ }^{60}$ Schmitt let him know one week later that such a meeting would be impossible because of his own travel plans. ${ }^{61}$ In late 1961, Kirchheimer sent Schmitt a copy of his book Political Justice, with the brief, formal dedication 'With compliments, your OK.'62 Schmitt is known to add handwritten comments in the books he read; they are few and far between in this one. He apparently did not read the sections on the legal proceedings relating to the Nazi crimes at all. But he did leave marks in those parts of the book that he believed pointed to his own concept of politics. Most of Schmitt's markings in this copy are in the

${ }^{57}$ As reported by George Schwab in response to a question about this matter from Volker Neumann, cf. Schwab (1988b, 462).

58 Letters from George Schwab to Carl Schmitt dated 11 June 1960 and 23 May 1961. Landesarchiv NordrheinWestfalen, Papers of Carl Schmitt, RW 265-148532 and 265-14824.

59 Letter from Otto Kirchheimer to Ernst Friesenhahn dated 20 November 1960. State University of New York, University at Albany, Special Collections \& Archives, Otto Kirchheimer Papers, Series 2, Box 2, Folder 61.

60 Letter from Otto Kirchheimer to Carl Schmitt dated 4 July 1961. Landesarchiv Nordrhein-Westfalen, Papers of Carl Schmitt, RW 265-7605.

${ }^{61}$ Letter from Carl Schmitt to Otto Kirchheimer dated 12 July 1961. State University of New York, University at Albany, Special Collections \& Archives, Otto Kirchheimer Papers, Series 2, Box 2, Folder 12.

62 Copy of Otto Kirchheimer, Political Justice. Landesarchiv Nordrhein-Westfalen, Papers of Carl Schmitt, RW 0265, No. 25665. 
section 'The Informer: Enemy from Within' in Chapter six 'The Defendant, His Lawyer, and the Court', on pp. 239-242. Apparently, Schmitt could not suppress his urge to add a handwritten comment underneath Kirchheimer's dedication of his book 'To the Past, Present, and Future Victims of Political Justice': Schmitt added: 'I do not compare the victims (to whom I-past, present and future-belong), I only compare the judges, C.S. ${ }^{\prime 63}$

In the meantime, Schwab had finished revising his doctoral dissertation. The defense in February 1962 again ended in an uproar. Kirchheimer pronounced that Schwab's work had remained apologetic throughout. Schwab had not even remotely understood Schmitt's role in the destruction of the Weimar Republic, and moreover, the work included several factually incorrect and polemical attacks against critics of Schmitt (Mehring 2014a, 506-508).

The committee did not accept the PhD thesis in its revised version, either. Schwab reported extensively to Schmitt about his failure in letters in the spring of 1962 and during his next visit in Plettenberg. Enraged, he told him that Kirchheimer had not accepted his description of Schmitt as a defender of the Weimar constitutional order. ${ }^{64}$ He abandoned a new attempt to obtain a doctorate at Columbia University with this topic. Instead, he decided to write a new dissertation on a different subject, which he completed successfully in 1968.

Schmitt felt the rejection of Schwab's doctoral dissertation to be an attack from New York directed personally against him. Following the same pattern as a year before in the case of Rudolf Smend, with whom he had been in contact for more than 40 years, he wrote to Ernst Forsthoff: 'What is being done to me is a disgrace. ${ }^{65}$ After Smend had called Schmitt an 'effective pacemaker of the violence-based Nazi system' in his history of the Berlin Faculty of Law, thereby publicly criticizing him because of his actions under the Nazi system, Schmitt categorically broke off contact to him. ${ }^{66}$ He reacted the same way in the case of Kirchheimer. He interpreted Schwab's description of the events during his defense as treason and deception on the part of Kirchheimer and refused any further contact with him from then on (Quaritsch 1999, 72 \& Mehring 2014a, 508).

For several years, Schwab tried, with Schmitt's support, to have the rejected manuscript accepted by American academic publishers. His attempts failed every time because of negative expert reviews. Furious, he and Schmitt made Kirchheimer responsible and after his death, his posthumous influence. It was only through Schmitt's personal intervention with the publisher Duncker \& Humblot that the text was finally published, in English, in Germany in $1970 .{ }^{67}$

\section{After the Break}

Any direct communication between Schmitt and Kirchheimer stopped after the Schwabepisode. Both, however, still followed the work and activities of the other. On the publication of the German edition of Kirchheimer's Politische Justiz in the summer of 1965 Schmitt noted to Armin Mohler: '[Kirchheimer's] book about political justice does not reach the actual problem', ${ }^{68}$ without, however, indicating to Mohler what he thought the actual problem of

${ }^{63}$ Copy of Otto Kirchheimer, Political Justice (page 5). Landesarchiv Nordrhein-Westfalen, Papers of Carl Schmitt, RW 0265, No. 25665.

${ }^{64}$ Cf. Letter from George Schwab to Carl Schmitt dated 11 March 1962. Landesarchiv Nordrhein-Westfalen, Papers of Carl Schmitt, RW 265-14851.

65 Letter from Carl Schmitt to Ernst Forsthoff dated 23 May 1968. In: Forsthoff/Schmitt (2007, 261).

66 The quote is to be found in Smend $(1960,542)$. On breaking off contact see Mehring (2010, 150f.).

${ }^{67}$ Cf. Schwab (1970). Reviewers accused the book of aiming to construct an apologetic legend that Carl Schmitt had kept a distance to the Nazi regime (cf. Richter 2001, 224-226). -Even in retrospect 25 years later, Schwab blamed a 'hostile attitude toward Schmitt' (Schwab 1988a, 81) on Kirchheimer's part for the failure of his dissertation. He repeated the accusation that a negative attitude toward Schmitt in the United States, for which Kirchheimer had been instrumental, was responsible for the fact that his manuscript on Schmitt was not accepted by any recognized publisher, even after Kirchheimer's death (cf. Schwab 1988a, 81).

68 Letter from Carl Schmitt to Armin Mohler dated 26 August 1965. Reprinted in Schmitt $(1995,354)$. 
political justice was. Kirchheimer too refrained from contacting Schmitt. But he did monitor the steps Schmitt took after he had rejected Schwab's dissertation. He reported to Ernst Friesenhahn:

By the way, our friend Carl Schmitt has managed again to take revenge on me semianonymously for not accepting his young man's doctoral dissertation. Signed "C.S.", he made an unfriendly comment in a German journal, I think it was "[Die] politische Meinung", by saying more or less that the whole book [Political Justice] actually doesn't say anything more than my essay from 1955. I somehow also suspect that he was behind a 10-page polemic in a third-rate American law review. ${ }^{69}$

Kirchheimer stopped sending Schmitt his publications as well. Schmitt's name was not even on the long list Kirchheimer sent to Günther Busch of Suhrkamp Publishing House in 1964 to whom copies of his book Politik und Verfassung were to be sent. ${ }^{70}$

It is well known that time and again, Schmitt undertook intensive efforts to guide the reception of his work (van Laak 1993, 71-73; Neumann 2015, 539). Back in his Bonn days, Kirchheimer had been able to closely observe Schmitt's discreet involvement in taking influence in this way (Mehring 2013, 438-440). The fact that Schwab's work provoked such a vehement rejection can be explained not least by Kirchheimer's assumption that Schmitt was pulling strings in an attempt at rehabilitation via the United States However, he by no means intended to categorically halt the reception of Schmitt's work in the United States, as Schwab later insinuated (Schwab 1988a, 81-83), which a letter of Kirchheimer's to Harvey Mansfield two years after the conflict about Schwab's work demonstrates: 'Schmitt should be presented to the American Political Science Community and on the basis of the numerous German studies [already] existing.' Two approaches were to be given preference: 'One may treat Carl Schmitt [...] either by studying his conceptual framework, including questions of logical consistency, or, by relating his concepts to the German political reality of his days. ${ }^{171} \mathrm{He}$ also included Schmitt in his teaching at Columbia University. On the reading list of his syllabus for the seminar 'The Political Institutions of Divided Germany' (1962/63) he recommended that the students read Schmitt's Verfassungslehre (Schmitt 1928), commenting it is the 'most influential constitutional interpretation on [the] basis of antidemocratic-authoritarian theory. ${ }^{72}$

Three years after Kirchheimer's death, Jürgen Seifert, a young left German assistant professor in Darmstadt, wanted to ask Schmitt about Kirchheimer. Schmitt sharply rejected the idea, responding to Seifert:

My postwar relations to Mr. Kirchheimer [...] ended in the summer of 1961, when I found out details about his behavior in Schwab's doctoral procedure. [...] the way Kirchheimer prevented the work from being accepted made me recognize an error I had made in $1927 .^{73}$ At this point of time, Kirchheimer had become a persona non

${ }^{69}$ Letter from Otto Kirchheimer to Ernst Friesenhahn dated 31 March 1963. State University of New York, University at Albany, Special Collections \& Archives, Otto Kirchheimer Papers, Series 2, Box 2, Folder 61. Cf. C. S. (1963); the polemic he mentioned was presumably the review of Political Justice by the anonymous author C. in 'Modern Law Review' volume 26, 1963, pp. 456-459.

70 Letters from Otto Kirchheimer to Günther Busch dated 19 and 20 November 1964. State University of New York, University at Albany, Special Collections \& Archives, Otto Kirchheimer Papers, Series 3, Box 2, Folder 68.

71 Letter from Otto Kirchheimer to Harvey Mansfield dated 4 June 1964. State University of New York, University at Albany, Special Collections \& Archives, Otto Kirchheimer Papers, Series 2, Box 1, Folder 51.

72 Minutes of the Faculty of Political Science 1957-62. Special Collection, Columbia University Archives.

73 Letter from Carl Schmitt to Jürgen Seifert dated 30 September 1968 (as cited in Seifert 1995, 120). As Reinhard Mehring pointed out, Schmitt wrote this response in close consultation with Schwab (cf. Mehring 2014a, 687). 
grata for him who did not even deserve to have received his doctorate from him 50 years ago.

Several years passed until Schmitt started to mention Kirchheimer again in more positive terms. Meanwhile he had discovered that some of his writings had found new resonance on the political left in Latin America, Germany and Italy. In 1976, he reported to Armin Mohler about a new posthumous edition of essays by Kirchheimer and took the opportunity to praise himself as a liberal-minded person:

A new Otto Kirchheimer volume is being published by Suhrkamp [...], with old material, including an excerpt from Kirchheimer's dissertation, which I accepted in Bonn in 1928; it is apparent: liberalism is a matter of the strong, not of the weak. ${ }^{74}$

And when Ingeborg Maus, a left political theorist with close ties with the Frankfurt School, received her doctorate in 1972, Schmitt congratulated her in a letter with the words: 'At this moment, I am moved by the memory of Otto Kirchheimer's doctorate [...] and by the joy I felt at the time of encountering a contradiction and understanding it.' And Schmitt added '[I] even though he was sure that he understood me better than I did myself. ${ }^{75}$ It is doubtful that Kirchheimer would have attributed the same to Schmitt.

\section{Conclusion}

Schmitt's unwillingness to take any personal responsibility for the destruction of the Weimar Republic and for his eager activities supporting National Socialism stood in the way of Kirchheimer's willingness to renew their almost friendly relationship between 1927 and 1930. Kirchheimer sharply criticized Schmitt and his disciples in his publications and his letters after 1945 and sided with the emerging type of parliamentary democracy in Western Germany. A few political positions characterize his writings on Schmitt and his disciples in the postwar era consistently: the rejection of the idea of incontestable state authority, the repudiation of the vision of a strong and neutral executive branch, and a reminder of the havoc that such a body of thought had wrought in recent German history.

It is worth mentioning that a revival of their earlier relationship appeared to be impossible from Schmitt's perspective as well. Schmitt deeply resented Jewish and other returning émigrés to Germany. Even though Kirchheimer stayed in the United States after 1945, Schmitt considered Kirchheimer to be one of those dangerous creatures with whom he believed he should communicate only very cautiously and in a purely strategic manner. His letters and diaries are filled with 'aggressive resentment' (Mehring 2014a, 413) and hateful remarks in particular against returning German-Jewish émigrés (van Laak 1993, 74-77; Neumann 2015, 534-537; Gross 2016, 105-120; Bendersky 2016, 139-142).

This constellation did not hinder Schmitt to try to instrumentalize Kirchheimer. It is well known how Schmitt used his former contacts and exchanges with Leo Strauss, Hugo Ball, and Walter Benjamin since the 1950s to appear as someone who had always respected Jews (Gross 2000, 12, 346; Mehring 2014b, 137-152). Concerning Kirchheimer, Schmitt tried to do the same. His most successful attempt in this regard was the construction of the legend that Kirchheimer had visited him multiple times and that it was primarily Kirchheimer who had pursued a friendly relationship after 1945 until he, Schmitt, broke with him because of

\footnotetext{
${ }^{74}$ Letter from Carl Schmitt to Armin Mohler dated 16 July 1976. Reprinted in Schmitt $(1995,410)$.

75 Letter from Carl Schmitt to Ingeborg Maus dated 24 January 1972 (as cited in Mehring 2013, 442).
} 
the Schwab-affair. As demonstrated previously, the only original source for this narrative is nobody but Schmitt himself. He disseminated this version of the story through informal conversations with young admirers of him like Reinhard Koselleck and Ernst Rudolf Böckenförde as well as later in an interview with Rainer Erd in the summer of 1980 (as cited in Neumann 1981, 239). It is not difficult to discern Schmitt's intention: This narrative was to function as a kind of certificate of clearance of political wrongdoing granted by a German Jew.

Kirchheimer noticed Schmitt's strategic intentions throughout their communication. The controversy around Schwab's doctoral project was fueled by his presumption that Schwab's dissertation was as a clever move to pursue Schmitt's political rehabilitation in the Federal Republic via the United States, thus trying to instrumentalize Kirchheimer in his function as a committee member as a person beyond suspicion. Kirchheimer was not willing to partake in this game and took an unapologetic stand against it. In his considerations on modern parliamentary democracy and in his critical observations Kirchheimer definitely sided with the political left of his times, but he did so without any flirtation with Schmittianism.

\section{Author Information}

An earlier version of this article has been presented at the Graduate Faculty of New School for Social Research in February 2019. I would like to thank Jay M. Bernstein, Carlos Forment, Andreas Kalyvas, Douglas Morris, Tobias Müller for their critical comments in the discussion and the two anonymous reviewers for their critical suggestions. In particular, I would like to express my gratitude to Hanna Kirchheimer-Grossman and Peter Kirchheimer for sharing some of their memories of their father with me. All German quotations in this article have been translated by the author, including letters by Otto Kirchheimer, Carl Schmitt, Rudolf Smend, Peter Schneider, Ernst Friesenhahn and Horst Ehmke.

\section{Competing Interests}

The author has no competing interests to declare.

\section{References}

Bendersky, Joseph W. 2007. 'Carl Schmitt's Path to Nuremberg: A Sixty-Year Reassessment.' Telos 72 (1987): 6-34. DOI: https://doi.org/10.3817/0687072091

Bendersky, Joseph W. 2016. 'Schmitt's Diaries.' In The Oxford Handbook of Carl Schmitt, edited by Jens Meierhenrich, Oliver Simons, 117-146. New York: Oxford University Press. DOI: https://doi.org/10.1093/oxfordhb/9780199916931.013.005

Buchstein, Hubertus. 2017. 'Einleitung.' In Otto Kirchheimer, Gesammelte Schriften Band 1: Recht und Politik in der Weimarer Republik, edited by Hubertus Buchstein, 15-126, Baden-Baden: Nomos. DOI: https://doi.org/10.5771/9783845282534-16

Buchstein, Hubertus. 2020a. 'Otto Kirchheimer and the Frankfurt School: Failed Collaborations in the Search for a Critical Theory of Politics.' New German Critique 47(2(140): 81-106. DOI: https://doi.org/10.1215/0094033X-8288139

Buchstein, Hubertus. 2020b. 'Einleitung.' In Otto Kirchheimer, Gesammelte Schriften Band 5: Politische Systeme im Nachkriegseuropa, edited by Hubertus Buchstein, 7-175, BadenBaden: Nomos. DOI: https://doi.org/10.5771/9783845290010-7

Burkhardt, Kai. 2013. Carl Schmitt und die Öffentlichkeit. Briefwechsel mit Journalisten, Publizisten und Verlegern aus den Jahren 1923 bis 1983. Berlin: Duncker \& Humblot. DOI: https://doi.org/10.3790/978-3-428-54092-1

Flechtheim, Ossip K., and Egbert Joos. 1991. Ausschau halten nach einer besseren Welt. Biographie, Interview, Artikel. Berlin: Dietz. 
Forsthoff, Ernst. 1950. 'Zur verfassungsrechtlichen Stellung und inneren Ordnung der Parteien.' In Die politischen Parteien im Verfassungsrecht, edited by Karl Loewenstein, 5-24. Tübingen: Mohr.

Frick, Verena. 2019. 'The Justicization of Politics: Constitutionalism and Democracy in Germany After 1949.' Redescriptions: Political Thought, Conceptual History and Feminist Theory 22(1): 18-34. DOI: https://doi.org/10.33134/rds.312

Gross, Raphael. 2000. Carl Schmitt und die Juden. Frankfurt/M.: Suhrkamp Verlag.

Gross, Raphael. 2016. 'The True Enemy. Antisemitism in Carl Schmitt's Life and Work.' In The Oxford Handbook of Carl Schmitt, edited by Jens Meierhenrich, and Oliver Simons, 96-116. New York: Oxford University Press. DOI: https://doi.org/10.1093/ oxfordhb/9780199916931.013.29

Heil, Susanne. 1996. Gefährliche Beziehungen, edited by Walter Benjamin und Carl Schmitt. Stuttgart: J.B. Metzler. DOI: https://doi.org/10.1007/978-3-476-03600-1

Hitschler, Daniel. 2011. Zwischen Liberalismus und Existentialismus. Carl Schmitt im englischsprachigen Schrifttum. Baden-Baden: Nomos. DOI: https://doi.org/10.5771/9783845229560

Kennedy, Ellen. 1986. 'Carl Schmitt und die ıFrankfurter Schule." In Geschichte und Gesellschaft 12(3): 380-419.

Kirchheimer, Otto. 1951. 'Werner Weber: Spannungen und Kräfte im westdeutschen Verfassungssystem.' In Otto Kirchheimer, Gesammelte Schriften Band 5: Politische Systeme im Nachkriegseuropa, edited by Hubertus Buchstein, 220-222. Baden-Baden: Nomos. DOI: https://doi.org/10.5771/9783845290010-220

Kirchheimer, Otto. 1954a. 'Parteistruktur und Massendemokratie in Europa.' In Otto Kirchheimer, Gesammelte Schriften Band 5: Politische Systeme im Nachkriegseuropa, edited by Hubertus Buchstein, 223-248. Baden-Baden: Nomos. DOI: https://doi. org/10.5771/9783845290010-220

Kirchheimer, Otto. 1954b. 'Ernst Rudolf Huber: Wirtschaftsverwaltungsrecht.' In Otto Kirchheimer, Gesammelte Schriften Band 5: Politische Systeme im Nachkriegseuropa, edited by Hubertus Buchstein, 266-270, Baden-Baden: Nomos. DOI: https://doi. org/10.5771/9783845290010

Kirchheimer, Otto, and Joseph H. Kaiser. 1956. 'Die Repräsentation organisierter Interessen.' In Otto Kirchheimer, Gesammelte Schriften Band 5: Politische Systeme im Nachkriegseuropa, edited by Hubertus Buchstein, 271-275. Baden-Baden: Nomos. DOI: https://doi. org/10.5771/9783845290010

Kirchheimer, Otto. 1957. 'The Political Scene in West Germany.' In Otto Kirchheimer, Gesammelte Schriften Band 5: Politische Systeme im Nachkriegseuropa, edited by Hubertus Buchstein, 342-356. Baden-Baden: Nomos. DOI: https://doi.org/10.5771/9783845290010

Kirchheimer, Otto. 1958. 'France from the Fourth to the Fifth Republic.' Social Research 25(4): 379-414.

Kirchheimer, Otto. 1959. 'The Administration of Justice and the Concept of Legality in East Germany.' The Yale Law Journal 68(4): 705-749. DOI: https://doi.org/10.2307/794398

Kirchheimer, Otto, and Nathan Leites. 1933. 'Bemerkungen zu Carl Schmitts 'Legalität und Legitimität." In Otto Kirchheimer, Gesammelte Schriften Band 1: Recht und Politik in der Weimarer Republik, edited by Hubertus Buchstein, 458-494. Baden-Baden: Nomos. DOI: https://doi.org/10.5771/9783845282534-459

Koselleck, Reinhard. 2019. 'Interview mit Claus Peppel über Carl Schmitt am 14. März 1994.' In Reinhart Koselleck. Carl Schmitt. Der Briefwechsel, edited by Jan Eike Dunkhase, 373391. Frankfurt am Main: Suhrkamp Verlag.

Luthardt, Wolfgang. 1976. 'Einleitung zu Otto Kirchheimer, Staatsgefüge und Recht des dritten Reiches.' Kritische Justiz 7(1): 33-39. DOI: https://doi.org/10.5771/0023-48341976-1-33 
Mehring, Reinhard. 2007. 'Otto Kirchheimer und der Links-Schmittismus.' In Der Staat des Dezisionismus. Carl Schmitt in der internationalen Debatte, edited by Rüdiger Voigt, 60-82. Baden-Baden: Nomos. DOI: https://doi.org/10.5771/9783845202471-59

Mehring, Reinhard. 2010. Auf der gefahrenvollen Straße des öffentlichen Rechts: Briefwechsel Carl Schmitt - Rudolf Smend 1921-1961. Berlin. Duncker \& Humblot.

Mehring, Reinhard. 2013. 'Kant gegen Schmitt. Ingeborg Maus über Volkssouveränität.' In Der Staat 52(3): 435-454. DOI: https://doi.org/10.3790/staa.52.3.435

Mehring, Reinhard. 2014a. Carl Schmitt. A Biography. Cambridge: Polity.

Mehring, Reinhard. 2014b. Kriegstechniker des Begriffs. Biographische Studien zu Carl Schmitt. Tübingen: Mohr Siebeck.

Mehring, Reinhard. 2017. Carl Schmitt: Denker im Widerstreit. Werk-Wirkung-Aktualität. München: Verlag Karl Alber.

Mehring, Reinhard. 2018. Vom Umgang mit Carl Schmitt. Baden-Baden: Nomos. DOI: https:// doi.org/10.5771/9783845293516

Müller, Jan-Werner. 2003. A Dangerous Mind. Carl Schmitt in Post-War European Thought. Yale UP. DOI: https://doi.org/10.1017/S0008938900005446

Neumann, Volker. 1981. 'Verfassungstheorien politischer Antipoden: Otto Kirchheimer und Carl Schmitt.' Kritische Justiz 14(3): 235-254. DOI: https://doi.org/10.5771/0023-48341981-3-235

Neumann, Volker. 2015. Carl Schmitt als Jurist. Tübingen: Mohr Siebeck. DOI: https://doi. org/10.1628/aoer-2018-0005

Preuss, Ulrich K. 2008. 'Carl Schmitt - Auch ein Lehrer der Studentenbewegung?' Ästhetik und Kommunikation 39: 65-76.

Quaritsch, Helmut. 1995. Positionen und Begriffe Carl Schmitts. Berlin: Duncker \& Humblot Verlag.

Richter, Emanuel. 2001. 'Der falsche Prophet: Carl Schmitt in den USA.' In Mythos Staat. Carl Schmitts Staatsverständnis, edited by Rüdiger Voigt, 215-267. Baden-Baden: Nomos. DOI: https://doi.org/10.5771/9783845254746-205

Schale, Frank. 2006. Zwischen Engagement und Skepsis. Eine Studie zu den Schriften von Otto Kirchheimer. Baden-Baden: Nomos.

Schale, Frank, Lisa Klingsporn, and Hubertus Buchstein. 2018. 'Otto Kirchheimer-Capitalist State, Political Parties, and Political Justice.' In SAGE-Handbook of Frankfurt School Critical Theory, edited by Beverley Best, Werner Bonefeld, and Chris O'Kane1, 105-122. London: SAGE Publications. DOI: https://doi.org/10.4135/9781526436122.n7

Scheuerman, William E. 1994. Between the Norm and the Exception. The Frankfurt School and the Rule of Law. Cambridge, MA: The MIT Press.

Scheuerman, William E. 1996. 'Introduction.' In The Rule of Law under Siege. Selected Essays of Franz L. Neumann and Otto Kirchheimer, edited by William E. Scheuerman, 1-27. Berkeley: University of California Press. DOI: https://doi.org/10.1525/9780520917347-002

Schmitt, Carl. 1928. Verfassungslehre. Berlin: Duncker \& Humblot.

Schmitt, Carl. 1950. Ex Captivitate Salus. Erfahrungen der Zeit 1945/47. Köln: Greven Verlag.

Schmitt, Carl. 1958. Verfassungsrechtliche Aufsätze aus den Jahren 1924-1954. Berlin: Duncker \& Humblot.

Schmitt, Carl. 1960. Die Tyrannei der Werte. Stuttgart: Klett-Cotta.

Schmitt, Carl. 1963. Der Begriff des Politischen. Text von 1922 mit einem Vorwort und drei Corollarien. Berlin: Duncker \& Humblot.

Schmitt, Carl. 1995. Briefwechsel mit einem Schüler. Berlin: Akademie Verlag. DOI: https://doi. org/10.1515/9783050071176

Schmitt, Carl. 2010. Tagebücher 1930 bis 1934. Berlin: Akademie Verlag. DOI: https://doi. org/10.1524/9783050061139 
Schmitt, Carl. 2015. Glossarium. Aufzeichnungen aus den Jahren 1947 bis 1958. Berlin: Duncker \& Humblot. DOI: https://doi.org/10.3790/978-3-428-54486-8

Schmitt, Carl, and E. Rudolf Huber. 2014. Briefwechsel 1926-1981. Berlin: Duncker \& Humblot.

Schmitt, Carl, and Ernst Forsthoff. 2007. Briefwechsel 1926-1974. Berlin: de Gruyter.

Schneider, Peter. 1957. Ausnahmezustand und Norm. Eine Studie zur Rechtslehre von Carl Schmitt. Stuttgart: Deutsche Verlags-Anstalt.

Schwab, George. 1970. The Challenge of the Exception: An Introduction of the Political Ideas of Carl Schmitt between 1921 and 1936. Berlin: Duncker \& Humblot.

Schwab, George. 1988a. 'Carl Schmitt through a Glass Darkly.' In Eclectica 17 (= Schmittiana 1) 71-72: 70-87.

Schwab, George. 1988b. 'Progress of Schmitt Studies in the English-Speaking World.' In Complexio Oppositorum. Über Carl Schmitt, edited by Helmut Quaritsch, 447-464. Berlin: Duncker \& Humblot Verlag.

Seifert, Jürgen. 1985. 'Theoretiker der Gegenrevolution. Carl Schmitt (1888-1985).' Kritische Justiz 18: 193-200. DOI: https://doi.org/10.5771/0023-4834-1985-2-193

Seifert, Jürgen. 1995. In Unterwegs zur Ebene über den Gegensatz, edited by Band V. Schmittiana and Piet Tommissen, 109-150. Berlin: Duncker \& Humblot.

Smend, Rudolf. 1960. 'Zur Geschichte der Berliner Juristenfakultät im 20. Jahrhundert.' In Ders. Staatsrechtliche Abhandlungen 2: 527-546. Berlin: Duncker \& Humblot. DOI: https://doi.org/10.1515/9783110848083-007

Söllner, Alfons. 1996. Deutsche Politikwissenschaftler in der Emigration. Opladen: VS Verlag für Sozialwissenschaften. DOI: https://doi.org/10.1007/978-3-322-90228-3

Söllner, Alfons. 2009. Fluchtpunkte. Studien zur politischen Ideengeschichte des 20. Jahrhunderts. Baden-Baden: Nomos.

Specter, Matthew G. 2016. 'Whats 'Left' in Schmitt? From Aversion to Appropriation in Contemporary Political Theory.' In The Oxford Handbook of Carl Schmitt, edited by Jens Meierhenrich, and Oliver Simons, 426-455. New York: Oxford University Press. DOI: https://doi.org/10.1093/oxfordhb/9780199916931.013.011

Taubes, Jacob. 1987. Ad Carl Schmitt. Gegenstrebige Fügung. Berlin: Merve.

van Laak, Dirk. 1993. Gespräche in der Sicherheit des Schweigens. Carl Schmitt in der politischen Geistesgeschichte der frühen Bundesrepublik. Berlin: Akademie Verlag. DOI: https://doi. org/10.1524/9783050081151

Weber, Werner. 1951. Spannungen und Kräfte im westdeutschen Verfassungssystem. Stuttgart: Friedrich Vorwerck.

Wieland, Claus-Dietrich. 1986. 'Carl Schmitt in Nürnberg (1947).' 1999. Zeitschrift für Sozialgeschichte des 20. und 21. Jahrhunderts 2: 96-122.

Wiggershaus, Rolf. 1995. The Frankfurt School. Its History, Theories, and Political Significance. Cambridge: MIT Press. DOI: https://doi.org/10.1111/j.1467-8675.1995.tb00031.x

Zwarg, Robert. 2017. Die Kritische Theorie in Amerika. Das Nachleben einer Tradition. Göttingen: Vandenhoeck und Ruprecht. DOI: https://doi.org/10.13109/9783666370489 
How to cite this article: Buchstein, Hubertus. 2021. "The Godfather of Left-Schmittianism? Otto Kirchheimer and Carl Schmitt after 1945." Redescriptions: Political Thought, Conceptual History and Feminist Theory 24(1): 4-26. DOI: https://doi.org/10.33134/rds.320

Submitted: 21 March 2020 Accepted: 17 February 2021 Published: 22 July 2021

Copyright: $\odot 2021$ The Author(s). This is an open-access article distributed under the terms of the Creative Commons Attribution 4.0 International License (CC-BY 4.0), which permits unrestricted use, distribution, and reproduction in any medium, provided the original author and source are credited. See http://creativecommons.org/licenses/by/4.0/. 